\title{
Burying the Past? The Post-Execution History of Nazi War Criminals
}

\section{Caroline Sharples}

In the aftermath of the Second World War, the Allies prosecuted several thousand former Nazis for war crimes and crimes against humanity. By 1949, 5,025 convictions had been secured in the western occupation zones of Germany alone, with around 500 men and women subsequently executed by Britain, France and the United States. ${ }^{1}$ Much of the existing literature on these cases has focussed on the organisation of the trials, points of procedure and legal precedents; or the failure to prosecute even more war criminals. ${ }^{2}$ There is also a growing canon of literature exploring the impact of war crimes trials on popular understanding of the Holocaust. ${ }^{3}$ However, aside from graphic descriptions of

I would like to thank James Campbell and Richard Ward for their constructive comments on an earlier draft of this article.

${ }^{1}$ Figures for the precise number of executions vary. The Jewish Virtual Library states 806 figures were sentenced to death, but that only 486 of these executions actually took place; the remaining war criminals had their sentences commuted to various periods of imprisonment or died within custody:

http://www.jewishvirtuallibrary.org/jsource/judaica/ejud_0002_0020_0_20618.html (accessed 25 April 2013). Reliable figures for the number of convictions and executions in the Soviet zone of occupation are unavailable.

2 See, for example: Shlomo Aronson, 'Preparations for the Nuremberg Trial: The OSS, Charles Dwork and the Holocaust', Holocaust and Genocide Studies, Vol. 12 (1998) pp. 257-281; Donald Bloxham, 'British War Crimes Trial Policy in Germany, 1945-1957: Implementation and Collapse', The Journal of British Studies, Vol. 42, No. 1 (2003) pp. 91-118 and "The Trial that Never Was": Why There Was No Second International Trial of Major War Criminals at Nuremberg', History, Vol. 87 (2002) pp. 41-60; George Ginsburgs, Moscow's Road to Nuremberg: The Soviet Background to the Trial (The Hague, 1996); Erich Haberer, 'History and Justice: Paradigms of the Prosecution of Nazi Crimes', Holocaust and Genocide Studies, Vol. 19, No. 3 (2005) pp. 487-519; Mark E. Spica, 'The Devil's Chemists on Trial: The American Prosecution of I.G. Farben at Nuremberg', Historian, Vol. 61, No. 4 (1999) pp. 865-883; Paul Weindling, 'From International to Zonal Trials: The Origins of the Nuremberg Medical Trial', Holocaust and Genocide Studies, Vol. 14 No. 3 (2000) pp.367-389; Robert Wolfe, 'Flaws in the Nuremberg Legacy: An Impediment to International War Crimes Tribunals' Prosecution of Crimes Against Humanity', Holocaust and Genocide Studies, Vol. 12, No. 3 (1998) pp. 434-453.

${ }^{3}$ On the impact of the Nuremberg Tribunal, see: Donald Bloxham, Genocide on Trial: War Crimes Trials and the Formation of Holocaust History and Memory (Oxford, 2001). On the resonance of subsequent Nazi war crimes trials, see: Lawrence Douglas, The Memory of Judgment: Making Law and History in the Trials of the Holocaust (New Haven, 2001); Devin O. Pendas, The Frankfurt Auschwitz Trial 1963-1965: Genocide, History and the Limits of the Law (Cambridge, New York, 2006); Rebecca Wittman, Beyond Justice: The Auschwitz Trial (Cambridge, Massachusetts, 2005); Caroline Sharples, West Germans and the Nazi Legacy (New York, 2012). 
the actual moment of execution within contemporaries' diaries and memoirs, the posthumous history of these war criminals has been hitherto neglected. ${ }^{4}$

Unlike most examples discussed in this volume, these executions were not public affairs; while notices of the sentence were disseminated via posters and the press, the criminals themselves were supposed to disappear from view without ceremony. ${ }^{5}$ The fundamental aim was to prevent the formation of shrines for Nazi sympathisers. This logic was very much bound up in the broader tenets of the denazification programme whereby the Allies hoped that the obliteration of physical reminders of the Third Reich from the German landscape would help eradicate the last vestiges of National Socialism. ${ }^{6}$ Monuments, historical sites and even street signs felt the effects of this process; likewise pre-1945 memorials to fallen soldiers and NSDAP comrades were 'cleansed' of Nazi insignia or destroyed altogether. ${ }^{7}$ Yet the representation and remembrance of the Nazi dead could not be so easily controlled. The criminal corpse evoked a powerful resonance long after the point of execution, affecting cultural memories of the recent past and popular understandings of the murderous nature of the Nazi regime. As such, the aftermath of the executions offers an important insight into the complexities of post-war memorial cultures. This article demonstrates this through an analysis of the precedent set by the Nuremberg Tribunal, before

\footnotetext{
${ }^{4}$ Accounts of the Nuremberg executions can be found in: Airey Neave, Nuremberg: A Personal Record of the Trial of the Major Nazi War Criminals in 1945-6 (London, 1978) pp. 348-349; Telford Taylor, The Anatomy of the Nuremberg Trials: A Personal Memoir (London, 1993) pp. 609611; Whitney Harris, Tyranny on Trial (1954) pp. 485-488.

5 There are distinctions between the treatment of Nazi war criminals in western and eastern Europe. High-ranking figures such as Rudolf Höss, the former Commandant of Auschwitz, and Arthur Greiser, former Gauleiter of the Reichsgau, were hanged publicly in Soviet-occupied Poland. On the subject of 'show trials' and public executions in the USSR, see: Alexander Victor Prusin, "Fascist Criminals to the Gallows!": The Holocaust and Soviet War Crimes Trials, December 1945-February 1946', Holocaust and Genocide Studies, Vol. 17, No. 1 (2003) pp. 1-30.

6 On the denazification of German towns and cities, see: Gavriel D. Rosenfeld and Paul Jaskot (eds), Beyond Berlin: Twelve Cities Confront the Nazi Past (Ann Arbor, 2008); Rudy Koshar, From Monuments to Traces: Artifacts of German Memory, 1870-1990 (Berkeley, 2000); Gavriel D. Rosenfeld, Munich and Memory: Architecture, Monuments and the Legacy of the Third Reich (Berkeley, 2000); Bill Niven and Chloe Paver (eds), Memorialization in Germany since 1945 (Basingstoke, 2009); Brian Ladd, The Ghosts of Berlin: Confronting German History in the Urban Landscape (Chicago, 1997).

7 Control Council Directive No. 30, 'Liquidation of German Military and Nazi Memorials and Museums', 13 May 1946; revised 12 July 1946.
} 
exploring the particularly turbulent post-execution history of war criminals hanged by the British in the small town of Hameln in Lower Saxony. ${ }^{8}$

\section{Disposing of the Nazi Dead}

The most well known set of executed Nazi war criminals were those condemned by the 1945-6 International Military Tribunal (IMT) at Nuremberg. Twenty-two leading names of the Third Reich were prosecuted for crimes against peace, war crimes, crimes against humanity and conspiracy, among them Hermann Göring, Julius Streicher and Joachim von Ribbentrop. Of these, 10 defendants were eventually hanged on 16 October 1946; Göring committed suicide the night before. ${ }^{9}$ The results of the executions were photographed and relayed in graphic form in the American press to serve as witness to the demise of these men and, by extension, the total defeat of the Nazi regime; the majority of UK newspapers held to a 'gentleman's agreement' not to publish the pictures on grounds of taste although that did not prevent the Sunday Pictorial (the precursor to the Sunday Mirror) or the Soviet Weekly from disseminating them. ${ }^{10}$ The images, taken by US Army photographer Edward F. McLaughlin, documented what had happened, attempted to dispel rumours that the hangings had been botched, and offered a moral lesson on the evils of fascism. While the precise manner of execution - and the time it took some of these men to die - nonetheless remained the subject of public interest in both Germany and the Allied nations, the corpses themselves were disposed of quietly. There was to be no opportunity for eulogising these

\footnotetext{
${ }^{8}$ For consistency, the German spelling of Hameln is adopted throughout this article, rather than the Anglicised 'Hamelin'. The former is also generally used in British primary sources from this period.

9 The ten executed individuals comprised of Hans Frank, Wilhelm Frick, Alfred Jodl, Ernst Kaltenbrunner, Wilhelm Keitel, Joachim von Ribbentrop, Alfred Rosenberg, Fritz Sauckel, Arthur Seyss-Inquart and Julius Streicher. Martin Bormann was tried and sentenced to death in absentia. For a detailed overview of the Nuremberg tribunal see: Bloxham, Genocide on Trial; Michael Biddis, 'The Nuremberg Trial: Two Exercises in Judgement', Journal of Contemporary History, Vol. 16, No. 3 (1981) pp. 597-615; Michael R. Marrus, 'The Holocaust at Nuremberg', Yad Vashem Studies, Vol. 26 (1998) pp. 5-41; Joseph E. Persico, Nuremberg: Infamy on Trial (London, 1995); Bradley F. Smith, Reaching Judgement at Nuremberg (London, 1977); Christian Tomuschat, 'The Legacy of Nuremberg', Journal of International Criminal Justice, Vol. 4, No. 4 (2006) pp. 800-829; Ann Tusa, The Nuremberg Trial (London, 1983).

10 See, for example, LIFE Magazine, 'Executed Nazi Leaders', 28 October 1946. On the British response to the photographs, see The National Archives (hereafter TNA) F0371/56935: Soviet Union 1946 and PCOM 9/635: Mr. Albert Pierrepoint declines to comment on official photographs of the Nuremberg hangings for the United Press Association.
} 
figures. The bodies were cremated and their ashes scattered along the River Isar, theoretically rendering them untraceable. ${ }^{11}$

Exactly what to do with the mortal remains of Nazi perpetrators had been the subject of lengthy discussion among the Allies; indeed draft instructions for the 'imposition and execution of death sentences' had been circulated as early as September 1944, while the Second World War was still raging. ${ }^{12}$ This initial document permitted the body of an executed war criminal to be buried by the next-of-kin. British responses to these instructions were positive, noting that such a procedure would be in accordance with German law. Indeed, the main points for concern at this stage focussed on ensuring that the condemned individual would have access to a chaplain, and that a minimum period of time was set between the sentence and actual execution to avoid seeming too 'hasty'.13

However, by October 1945, just weeks before the opening of the IMT, it was evident that other measures were being contemplated. The Legal Division of the Control Commission for Germany in the British occupation zone charged the Special Legal Research Unit (SLRU) in London with investigating whether the burial of executed prisoners within prison grounds was prohibited under German law. ${ }^{14}$ This shift, from quiet familial burials to disposal by prison staff, may owe much to the fact that the war was now over, the camps had been liberated and the Allies were struggling to come to terms with the horror of Nazi atrocities. Arguably, they now had a better idea of the sort of perpetrators they

\footnotetext{
${ }^{11}$ Nonetheless, it should be noted that memorials do exist to three of those executed in the wake of the IMT. Alfred Jodl is recalled on an elaborate cenotaph in his family's burial plot at Fraueninsel Cemetery in Chiemsee, and Wilhelm Keitel has memorial stones in both Bad Gandersheim and Ohlsdorf Cemetery in Hamburg. Ribbentrop, meanwhile, has been memorialised in his wife's family's plot in Biebrich, a borough of Wiesbaden. Knowledge (and photographs) of these memorials persists today online - see, for example, findagrave.com, 'Alfred Jodl',

http://www.findagrave.com/cgi-bin/fg.cgi?page=pv\&GRid=7010\&PIpi=2255578 (accessed 10 August 2013).

12 'Instructions for the Imposition and Execution of Death Sentences', September 1944, TNA F01060/930: Execution of Death Sentences: Policy.

13 TNA F01060/930: Ministry of Justice Control Branch to Legal Division, 23 September 1944.

14 TNA F01060/90: Burial of Executed Prisoners: Question by the Legal Advice and Drafting Branch, Legal Division, Control Commission for Germany (British Element), Lübeck, 19 October 1945.
} 
would be dealing with. At the same time, though - and despite the apparent reluctance to be seen as riding roughshod over existing German customs and sensibilities - it seems that the British were keen to extend domestic policies regarding the disposal of executed prisoners to their treatment of Nazi war criminals in Germany. Since the nineteenth century, those executed in Britain had been buried in the grounds of the relevant prison; adopting the same principle in occupied Germany thus offered consistency with English law. ${ }^{15}$

The SLRU findings confirmed that there was no specific provision in German law to prevent burials from taking place within prison grounds. However, it was also noted explicitly that in 'pursuant to section 454 of the German Criminal Code of criminal procedure, the body of the executed prisoner must be handed over to the next-of-kin at their request for a simple burial without ceremony'.16 In accordance with a decree of 22 October 1935, bodies left unclaimed by relatives would be handed over for medical research at the nearest university or, if this facility renounced its claim, to the police authorities who would then assume responsibility for burying the remains; 'presumably', noted the SLRU, this could take place within the prison precincts. ${ }^{17}$

This correspondence between the SLRU in London and the occupation authorities in Germany is significant for several reasons. Firstly, it must be noted that the decrees that the researchers were citing were formulated during the Third Reich. Adhering to these laws after 1945 contradicted the wider Allied

15 Paragraph 6 of the 1868 Capital Punishment Amendment Act stipulated: 'the body of every offender executed shall be buried within the walls of the prison within which judgment of death is executed on him' - Legislation.gov.uk, 'Capital Punishment Amendment Act', 29 May 1868, http://www.legislation.gov.uk/ukpga/Vict/31-32/24 (accessed 24 February 2014). For details on this process see, for example, TNA PCOM 8/220 and PCOM 8/221: Method of Burial (19031925). Subsequent developments in the history of executions in the British zone also suggest a determination to ensure activities reflected domestic practices. From March 1947, for example, condemned German war criminals were granted a period of 21 days between the promulgation of their sentence and actual execution. This echoed English law which allowed prisoners three Sundays after the final decision on their case to write any last letters and prepare themselves for their fate. See: A.J.H. Dove, General Officer, HQ BAOR to Zonal Executive Offices, Lübeck, 30 July 1948, TNA F01032/783: Procedure for Execution of Death Sentences, Vol. 2.

16 TNA F01060/90, Report by the British Special Legal Research Unit, London, 19 October 1945. Author's emphasis.

17 Ibid. Subsequent memoranda within Legal Division noted that a 1940 German law allowed a 24 hour window for bodies to be handed over to the next of kin after an execution. See TNA F01060/239: Executions Policy Vol. 1. 
denazification programme and the efforts to discredit the entire Nazi system. It also equated Nazi war criminals with the remains of those executed by the Nazis themselves, blurring the distinction between victims and perpetrators. Ironically, the Minister of the Interior responsible for this existing legislation Wilhelm Frick - was one of those about to stand trial at Nuremberg and who would himself be executed in October 1946.18

Secondly, for all these apparent efforts to understand the prevailing German legal situation, the contents of this report were ultimately ignored by the British, perhaps as a result of the above issue. The first test of this was seen as early as November 1945 following the suicide of Dr. Robert Ley, the former head of the German Labour Front. His daughter, Renate, appealed for the release of her father's body, requesting his remains be transferred from Nuremberg for internment in his birthplace of Nümbrecht, a town now under British control. Although Ley had died before the opening of the IMT, Renate's request was denied and Ley was not handed over to his relatives. The British argued that responsibility for his corpse rested with the international court that would have tried him. ${ }^{19}$ The authority upon which the British based this decision is unclear; it may simply have been a means of evading responsibility for Ley's remains which, consequently, were cremated with the ashes scattered in an undisclosed location. ${ }^{20}$

\footnotetext{
${ }^{18}$ For further discussion of the use of executed corpses for medical research in Nazi Germany, see Michael Viebig, '"...the Cadaver can be Placed at your Disposition Here." Legal, Administrative Basis of the Transfer of Cadavers in the Third Reich, its Traces in Archival Sources', Annals of Anatomy, Vol. 194(2012) pp. 267-273.

19 TNA F01060/90, Letter from HQ Internal Affairs and Communications Division to Office of the Chief of Staff, Main HQ, Control Commission for Germany, Lübeck, 13 November 1945. The original request by Renate Ley was reported in Letter from Military Governor, Iserlohn, to Secretariat, Main HQ, Control Commission for Germany, 5 November 1945.

20 The Prussian Penal Code of 1851 stated that 'the body of a criminal who commits suicide to escape the execution of a sentence pronounced against him is to be buried at night by the common executioner at the usual place of execution for criminals' - R.S. Guernsey, Suicide: History of the Penal Laws relating to it in their Legal, Social, Moral and Religious Aspects in Ancient and Modern Times (New York, 1875). However, by the time of Ley's death, this legislation would have been superseded by that of the Kaiserreich, Weimar Republic and, of course, the Third Reich, none of which directly addresses the fate of suicides in prison. In Britain, there had also been incidents of prison suicides being buried in the same manner as executed prisoners. See: Trevor James, Prisoners of War at Dartmoor: American and French Soldiers and Sailors in an English Prison during the Napoleonic Wars and the War of 1812 (Jefferson, North Carolina, 2013) p. 221; 'Newgate Prison and Tyburn', Famous Outlaws, http://www.criminals.lt/page.php?al=newgate_prison_and_tybur (accessed 28 February 2014).
} 
By December 1945, the issue of disposal within the British occupation zone was becoming more urgent. While the IMT remained in its early stages, the trial of 45 former Bergen-Belsen personnel had already reached its conclusion in Lüneburg. Death sentences were confirmed on 11 of these defendants yet up until just two days before the executions were carried out, the occupation authorities continued to debate the best means of disposing of the remains. ${ }^{21}$ Among the suggestions was 'Operation Overboard', committing the coffins to the sea, although the logistics of organising special transports and shipping eventually led to this being ruled out in favour of secret burial in prison grounds. ${ }^{22}$ Throughout the discussions, there was a distinct tension between the desire for discretion, guarding against the formation of a 'martyrdom legend' or the 'possibility of graves becoming... places of national hero-worship'; and the need to show justice had been served. ${ }^{23}$ Cremation (as would be used for those convicted by the IMT) was ruled out by the British 'as this would remove all means of identification and evidence of means of death'.24 This line of argument, also seized upon by critics of 'Operation Overboard', is inherently contradictory given that the British authorities would, in any case, refuse to divulge either physical remains or burial information to relatives of the deceased.

The measures drawn up by the Allies to cover the death of any convicted war criminal in prison also contravened the findings of the SLRU regarding next-ofkin. Seven of the IMT defendants (Karl Dönitz, Walter Funk, Rudolf Hess, Konstantin von Neurath, Erich Raeder, Baldur von Schirach and Albert Speer)

\footnotetext{
21 The executed Belsen personnel comprised Juanna Bormann, Wilhelm Dörr, Karl Franzische, Irma Grese, Franz Hössler, Fritz Klein, Josef Kramer, Ansger Pinchen, Franz Stofel, Elisabeth Volkenrath and Peter Weingärtner. All were hanged in Hameln prison, 13 December 1945. For an overview of the Belsen trial, see: John Cramer, Belsen Trial 1945: Der Lüneberger Prozess gegen Wachpersonal der Konzentrationslager Auschwitz und Bergen-Belsen (Göttingen, 2011); Raymond Phillips, Trial of Josef Kramer and Forty-Four Others (The Belsen Trial), (London, 1949); A.P.V. Rogers, 'War Crimes Trials under the Royal Warrant: British Practice, 1945-1949', International and Comparative Law Quarterly, Vol. 39 (1990) pp. 780-800.

22 TNA F01060/239: Executions Policy Vol. 1. Legal Division to Secretariat, 'Burial of War Criminals', 6 December 1945.

${ }^{23}$ Correspondence in TNA F01060/239, Concomb to British War Crimes Executive, Nuremberg, Bercombe (Political Division) and Secretariat (undated); Bercomb to Concomb, 7 December 1945; Concomb to Bercomb, 8 December 1945; Exfor to Concomb, 11 December 1945.

24 TNA F01060/239, I.A and C Division to Legal Division, 'Disposal of Bodies of War Criminals', 8 December 1945.
} 
would eventually be imprisoned in Spandau to serve sentences ranging from 10 years to life. With two of these figures already aged 70 or over at the time of their sentencing, the likelihood of their dying within prison was a very real prospect. An agreement reached between all four Allied powers at the end of 1947 stated that, in such an event,

The prisoner will be cremated... The ashes will be secretly scattered by the four prison directors in the vicinity of, but not close to, the prison. No information will be given concerning the prisoner's death until after the final and secret disposition of the ashes. Relatives of the deceased will then be notified of the time and cause of death and of the fact of burial. ${ }^{25}$

This seeming disregard for relatives' sense of grief would prompt much German criticism of Allied behaviour and, by extension, enable the West German public to cast significant doubt on the validity of the war crimes convictions handed down by Allied tribunals. The executed corpse thus became another symbol of victors' justice.

Looking beyond the IMT to other Allied war crimes tribunals confirms that the disposal of Nazi perpetrators was far from straightforward. Inter-allied agreement quickly broke down and the treatment of executed war criminals varied between occupation zones due to a combination of practical and ideological reasons. In the Soviet-controlled East, there were instances of executed war criminals being sent to the nearest university for medical research or being cremated. ${ }^{26}$ Burial, meanwhile, remained the preferred disposal method in the west, although even here there were notable differences between the Americans who offered relatives the option of claiming the remains, and the

\footnotetext{
25 TNA F01060/4122, Letter from Maxwell D. Taylor, US Commander, Berlin, to John McCloy, US High Commissioner for Germany, 11 January 1951 and Letter from the Office of the Legal Advisor, Wahneheide to G.O.C, British Troops, Berlin, 22 January 1951. By the start of the 1950s, McCloy was keen to amend what he viewed as an 'unfortunate' procedure. As it was, only Hess died within Spandau, committing suicide in 1987 at the age of 93. By this time, the procedure had been amended. He was buried first in secret but then, in accordance with his will, re-interred in his family's plot at Wunsiedel but exhumed in 2011 as his grave increasingly became a site of pilgrimage for Neo-Nazis. Spandau prison itself was also destroyed. See, for example, Der Spiegel, 'Wunsiedel: Grabstätte von Hitler-Stellvertreter Heß aufgelöst' (21 July 2011).

${ }^{26}$ For example, the remains of the 21 war criminals executed in the wake of the 1947 Auschwitz trial in Poland were taken to the University of Krakow.
} 
British, who persisted in the notion of a discreet interment conducted by prison staff. 27 The latter's stance was confirmed in a directive from the Office of the Deputy Military Governor in December 1945 which stated:

Bodies of executed war criminals shall be buried without publicity or ceremony and without any signs to indicate positions of their graves, in unconsecrated ground in the prison precincts. ${ }^{28}$

In practice, the remains of these individuals managed to attract a great deal of publicity throughout the post-war era. Indeed, far from curtailing discussion of the executed criminals, the Allies' handling of the corpses had the opposite effect, facilitating a victimhood mythology and leaving friends and relatives determined to know more about their loved ones' final moments. It quickly became clear that the Nazi past would not be easily buried.

\section{The Executed of Hameln}

One prison precinct that proved particularly controversial after 1945 was Hameln, which lay within the British zone of occupation. The region polled some of the highest NSDAP votes before 1933, and had been proud to be the birthplace of the parents of Horst Wessel, a Nazi party activist who was transformed into one of the movement's earliest martyrs following his death in $1930 .{ }^{29}$ In August 1933, Hameln granted Wessel's mother, Margarete, honorary citizenship and, following a lengthy design process, the town dedicated an imposing monument to Wessel in February 1939.30 A further propaganda spectacle was created when, between 1933 and 1937, the Nazis used nearby Bückeberg for their

\footnotetext{
27 Corpses left unclaimed in the American zone were buried in Spöttingen cemetery, Landsberg am Lech. For further details see: Thomas Raithel, Die Strafanstalt Landsberg am Lech und der Spöttinger Friedhof, 1944-1958 (Oldenbourg, 2009). In 1988, the cemetery was declared a protected historical site and the upkeep of the war criminals' graves is thus paid for by the taxpayer.

28 TNA F01060/4122: Executed War Criminals - Burial Policy.

29 'Kreis Hameln-Pyrmont Parlamentswahlen', Wahlen in der Weimarer Republik, http://www.gonschior.de/weimar/php/ausgabe_gebiet.php?gebiet=1357 (accessed 1 March 2014).

30 Daniel Siemens, The Making of a Nazi Hero: The Murder and Myth of Horst Wessel (London, 2013) pp. 155-163.
} 
annual harvest festival celebrations. ${ }^{31}$ Hameln prison, meanwhile, had already gained notoriety when it was used to detain political opponents, more than 200 of whom were murdered by the Nazis. ${ }^{32}$

From 1945, this prison became the centre for executions in the British zone of occupation. War criminals who had been sentenced to death by various military tribunals across northern Germany, including Lüneburg, Wuppertal, Essen and Hamburg, were transferred to Hameln in the final days before their execution. There, they were dispatched by the renowned British executioner, Albert Pierrepoint, who made special flights to Germany for each set of hangings. Just why Hameln was selected for these executions is unclear, although arguably its small size and position on the banks of the River Weser gave it an added layer of security over places like Werl prison which had a more central, urban location. ${ }^{33}$

Among the most notorious Nazi perpetrators to be executed here were Josef Kramer, former Commandant of Natzweiler-Stuthof and Bergen-Belsen concentration camps, and Irma Grese, a guard at Ravensbrück, Auschwitz and Belsen. Both were responsible for the murder of thousands of people during the Holocaust: Kramer was in charge of the gas chambers at Auschwitz for most of 1944, while Grese was renowned for issuing sadistic beatings and setting her dogs on prisoners. At 22, Grese was the youngest war criminal to be hanged by the British. She was also one of just nine women to be executed at Hameln, all of whom were found guilty of atrocities in Belsen or Ravensbrück. Among the men

\footnotetext{
${ }^{31}$ Mats Burström \& Bernhard Gelderblom, 'Dealing with Difficult Heritage: the Case of Bückeberg, Site of the Third Reich Harvest Festival', Journal of Social Archaeology, Vol. 11, No. 3 (2011) pp. 266-282.

32 On the history of Hameln prison during the Third Reich, see Bernhard Gelderblom, 'Der Zuchthaus Hameln in der NS-Zeit',

http://www.gelderblom-hameln.de/zuchthaus/nszeit/zuchthausnszeit.html (accessed 1 July 2013). Hameln also witnessed antisemitic violence, especially between 1933 and 1935. 74 per cent of its Jewish population had perished by the end of the Third Reich - a total based on figures provided in Shmuel Spector \& Geoffrey Wigoder (eds), The Encyclopaedia of Jewish Life Before and After the Holocaust (New York, 2001) p. 492.

33 This is certainly a suggestion put forward by local Hameln historian, Bernhard Gelderblom. Details on the arrangements for these executions can be seen in TNA F01060/239-243: Executions Policy Vols. 1-5; F01060/244: Executions: Judicial Hangings Instructions. In a memorandum sent by Legal Division to 229 'P' Mil.Gov.Det., Hannover, 1 December 1945 (TNA F01060/239), it was noted that the towpath running beside the prison would be closed to the public, although it is unclear whether this was to be a permanent move, or a measure implemented solely on days of executions.
} 
to be hanged were guards from other concentration camps (such as Natzweiler and Neuengamme), former Gestapo officers, medical personnel and, in the case of Bruno Tesch and Karl Weinbacher (executed in May 1946), two figures who were responsible for developing Zyklon B. In addition to these Holocaust perpetrators, the British also tried and executed a number of people for crimes perpetrated against Allied military personnel, including those responsible for shooting British POWs following the 'Great Escape' from Stalag-Luft III. In all, a total of 155 convicted war criminals were hanged in Hameln, 90 of whom were buried in the prison grounds as directed. ${ }^{34}$

However, by the end of 1946, the available burial space was becoming full, even though corpses were buried three deep. The overcrowding was then exacerbated by a change in policy concerning the preferred manner of execution. Up until this point, executions of war criminals sentenced by British Military Courts could be carried out by judicial hanging or firing squad. ${ }^{35}$ The British Army of the Rhine (BAOR) was responsible for organising 'shooting parties' to carry out the latter method. Army officials noted that, 'while this duty was naturally disliked, there were no real objections which could be raised to this procedure'. In 1947, however, the imminent arrival of younger men on their National Service was deemed a different matter. Army officials were wary of the psychological effects such duties might have upon them, and the greater risk of shots going wide if inexperienced personnel were pulling the trigger. ${ }^{36}$ Hanging, by a professional, experienced and discreet figure such as Pierrepoint was now considered the better method; indeed, Pierrepoint would have sole responsibility for dispatching condemned prisoners as it was felt no one else was suitably qualified for the role. Not only did Hameln already have an established

\footnotetext{
${ }^{34}$ Another 47 people were executed for crimes committed after the end of the war but buried in the same manner - see TNA F01060/4122, Bonn Telegram No. 133, 6 March 1954. Precise details on all the individuals executed at Hameln can be found in TNA F01060/239-243 and Peter Krone ed., 'Hingerichtetengräber' auf dem Friedhof Wehl, Hameln: Historische Dokumentation (Hameln, 1987).

35 German nationals sentenced by German courts or Control Commission Courts for crimes against humanity faced the guillotine, as did Displaced Persons who were found guilty of crimes such as murder or armed robbery during the immediate post-war period. See TNA F0 945/318: Death Sentences: Execution.

36 TNA FO 945/318: Death Sentences: Execution, Simpson to Crawford, 1 March 1947; TNA 1060/240: Executions Policy, Vol. 2, HQ BAOR to Legal Division,13 June 1947.
} 
and efficient system in place for this; it also offered the only set of hanging apparatus in the British zone. ${ }^{37}$

As Hameln prison consequently ran out of space, the decision was taken to bury the remaining executed war criminals in an annexe to a public cemetery, Friedhof am Wehl, two miles away. ${ }^{38}$ This same cemetery already held bodies of the civilian war dead and, in an area known as Plot CI, those killed by the Nazis. With the war criminals interred in Plot CIII, the remains of victims and perpetrators were thus effectively laid side by side. From May 1947, the bodies of the executed were transported in covered trucks, usually at night, and accompanied by military police who had carefully removed their red caps. Again, the whole aim was to be as unobtrusive as possible but the British had failed to fully appreciate the effect that preparations for these executions (and burials) would have on public awareness of these events. In January 1948, for example, news of an imminent set of executions was leaked by a Hamburg newspaper. Officials within Legal Division blamed this on a number of factors, including the prison governor's 'sudden booking' of hotel rooms in Hameln for the mandatory witnesses and the 'necessity to open graves in a public place sometime before the executions actually take place'. ${ }^{39}$ Likewise, the authorities had not reckoned with the intense interest harboured by the friends, relatives and former comrades of the executed war criminals.

Over the next few years, the British received numerous petitions from these groups, who were anxious to learn more about their loved ones' final resting places and the circumstances in which they had been buried. A letter from a Herr Schmidt from Kiel, for example, inquired into the fate of his son, hanged in February 1947. Schmidt wrote:

\footnotetext{
37 On changes in execution policy, see TNA F0 945/318: Death Sentences and TNA F01060/240: Executions Policy, Vol. 2.

38 TNA F01050/1488: Burials, 'Letter from the Secretariat, I.A. \& C. Division to Public Safety Division', 23 November 1946. For logistical arrangements for these transports, see TNA F01024/101.

39 TNA F01060/242: Executions Policy, Vol. 4, L.H. Barnes to J.C. Piegrome, 'Executions', 24 February 1948.
} 
Being his father, I should like to know whether the hanged persons have been buried with or without a coffin and whether the graves can be recognised, and whether they are being looked after. And would you kindly let me know whether a parson performed the burial service and if possible his name and address? ${ }^{40}$

Similarly, a Frau Schneider from Munich enquired about the fate of her 'good husband', who had been executed in February 1948. She begged the Military Government to tell her the number of his coffin and whether she might buy and tend the grave. ${ }^{41}$ Frau Lommes, meanwhile, made several requests over the course of a year to try and have the remains of her executed husband transferred to his hometown of Neuendorf, stating: 'both my children and myself have an innate desire for their father to be buried in Neuendorf and for him to have a Christian burial'. 42

As Monica Black has illustrated in her study of twentieth century Germany, there was a longstanding, popular attachment to the concept of a 'dignified' place of rest among German society.43 Even at the height of Allied air raids during the Second World War, the Berlin authorities had remained committed to burying the civilian dead as individuals; mass graves were viewed not only as an ignominious breach of custom, but also a fate reserved for so-called 'racial enemies' of the Reich. ${ }^{44}$ The eventual scarcity of coffins by spring 1945, notes Black, created 'a lasting moral shock' among the population. ${ }^{45}$ Concerns over the

\footnotetext{
40 TNA F01060/4122, Letter to the Cemetery Administration, Hameln by Ernst Schmidt, Kiel, 26 November 1950. This is most likely to refer to Oskar Schmidt, who was involved in the summary execution of Allied prisoners of war who had tried to escape Stalag Luft III in March 1944. This would, of course, become the subject of the 1963 film The Great Escape. The trial, however, only began in July 1947; the executions were carried out in February 1948.

41 TNA F01024/101, Letter to the Military Government by Therese Schneider, Munich, 10 May 1948. Johann Schneider was another of those convicted for the Stalag Luft III murders before a Hamburg tribunal.

42 TNA FO1060/240, Letter from Frau Berta Lommes to the British Liaison Det., 17 April 1947. Requests were also sent on her behalf by the local curate, 18 April 1947 and the family lawyer, 12 February 1948. Hermann Lommes was executed on 15 May 1946 for his role in the shooting of Allied airmen at Dreierwalde airfield in March 1945.

${ }^{43}$ Monica Black, Death in Berlin: From Weimar to Divided Germany (New York, 2010). For more on post-war German attitudes to the dead, see Alon Confino, Paul Betts \& Dirk Schumann (eds), Between Mass Death and Individual Loss: The Place of the Dead in Twentieth-Century Germany (New York, 2008).

${ }^{44}$ Ibid, pp. 121-122.

45 Ibid., p. 131.
} 
fate of the Hameln executed can, therefore, be regarded as a continuance of these older sensibilities regarding 'decent' burial. Likewise, the letters penned by the Lommes, Schneider and Schmidt families echo efforts by Berliners to learn more about the fate of relatives killed in the final throes of the war. Black argues that the latter constituted an important means for 'individualizing' deaths and preserving the dead from the 'anonymity, horror and even shame of "mass" experience'.46 Evidence of similar behaviour being applied to the executed war criminals suggests a desire to present these characters too, as victims of the war, and to rescue them from apparent disgrace.

Each of these sources is highly emotive, conveying the authors' desperation and frustration at simply not knowing what has become of their loved ones, yet the British were steadfast in their refusal to release any information on the executed war criminals. Responses were usually curt, stating simply that no information could be divulged. For those, like Frau Lommes, who pointed to religious factors, a lengthier response could sometimes be forthcoming, offering the assurance that the deceased had received the last rites and been 'accorded a decent burial', although given that Lommes was buried in an unmarked prison grave along with two of his executed comrades, the 'decency' of his resting place can clearly be called into dispute. ${ }^{47}$

Undeterred, some Germans continued to write to the authorities, or they pressed German institutions to lobby on their behalf, clearly hoping this might carry more weight. The revived German War Graves Commission (a charitable organisation originally established in December 1919 to maintain First World War graves) ended up playing a significant part in this, ${ }^{48}$ and the Lower Saxony Ministry of Justice also got involved, insisting:

Many of the dead buried in the prison yard at Hameln are unlikely to have been mean criminals. At the least, the acts of many of them would, at the present time, no longer be punished with the death penalty. They left

\footnotetext{
46 Ibid., p. 173.

47 TNA F01060/240, Penal Branch, Legal Division to Herr Kuratus R. Liebenstein, 7 June 1947.

48 TNA F01060/4122, Letter from Volksbund Deutsche Kriegsgräberfürsorge, Landesverband Niedersachsen (undated).
} 
relatives who desire to remember the dead at their graves. Their right to do so cannot be disputed all the less as, according to German customs of former times, the corpse of an executed person would, at their request, be handed to the relatives. ${ }^{49}$

The meaning of the phrase 'former times' in this statement is unclear, but there is scope for viewing this as an implicit comparison with practices under the Third Reich. As previously highlighted, the British were aware of the previous decrees on this issue; by proceeding to ignore those customs and refuse to divulge information on the disposal of the corpses, they opened the way for a host of West German criticism. An impression was thus being formed that the Nazis were more honourable in dealing with the dead than the Allied occupiers. Meanwhile, by questioning the criminal nature of these figures, this source betrays incomprehension, or perhaps even a wilful ignorance, of the nature of National Socialist atrocities. It is worth emphasising that around 45 per cent of war criminals executed in Hameln were linked to concentration camps. ${ }^{50}$ Some of them, then, were very 'mean' characters indeed.

It is therefore clear that an interesting discussion was taking place in Hameln. Written protests about the lack of information were accompanied by attempts at enacting physical memorials, particularly to those interred within Friedhof am Wehl, to which the West German population had ready access. As with the burials within the prison grounds, these graves were unmarked and, commenting on the visitors making their way to this site, the Office of the Legal Advisor in the British zone reassured Foreign Office staff that 'the Germans do not know which grave is which in the case of more than one execution being carried out on the same day... In the case of single executions, they would know by the fact of there being one new grave.' 51 However, the lack of specific markers did not deter people from repeatedly laying flowers. In July 1950, for example, a

\footnotetext{
${ }^{49}$ Author's emphasis. TNA F01060/4122, Letter from Dr Meyer-Abich of the Ministry of Justice, Niedersachsen, to the Office of the Legal Advisor, Wahnerheide, 10 November 1952 . The argument that many of these acts would 'no longer be punished with the death penalty' is somewhat redundant given that the Basic Law of the newly constituted Federal Republic of Germany abolished capital punishment altogether.

${ }^{50}$ Data compiled by the author from TNA F01060/239-243 and Krone, 'Hingerichtetengräber' auf dem Friedhof Wehl, Hameln.

${ }^{51}$ M.F.P. Herchenroder, Office of the Legal Advisor, Wahnerheide, to H.W. Evans, Foreign Office,

21 August 1953. TNA F0371/104149.
} 
routine inspection of the cemetery by the British Governor of Werl Prison, Lt. Col. E.R. Vickers, reported the presence of three wreathes, some freshly-cut flowers and planted geraniums. Vickers confessed that he 'felt a bit of a vandal and removed all these'.52 His action was approved by the British Zonal authorities, although it was suggested he did this 'as quietly as possible'. ${ }^{53}$ This was not the only time that Vickers found wreathes placed on the burial plot, and it seems that a particularly significant number of flowers were left during key points in the religious calendar such as All Soul's Day and the first Sunday of Advent, underscoring the persistence of Christian traditions for mourning the dead. The reports sent by Vickers to the Office of the Legal Advisor during this period reveal his continued discomfort at 'interfering' with these offerings. In 1948 , there was a rumoured local proposal to place wooden crosses on the site; this too was quickly quashed by the British. 54

By 1953, though, the matter of the Hameln graves reached new proportions. By this time, the Federal Republic had gained sovereignty, and control of Hameln prison was handed back to the Germans. A series of sensationalist articles then appeared in the West German press, all apparently 'exposing' the fact that German nationals had been executed and buried in this town. This coverage raises questions about the level of knowledge that existed in West Germany regarding war crimes trials. The proceedings were, of course, public affairs. They were reported in the press and members of the public could go and observe the proceedings first-hand if they so wished; notices of the executions had also been routinely posted by the prison authorities. Likewise, the previous petitions orchestrated by relatives of the deceased, the German War Graves Commission and the Ministry of Justice had already underscored the layers of local interest in these war criminals. However, as the national West German press now got hold of the story, it was treated as the discovery of a major scandal. Numerous articles stressed the clandestine nature of these burials, and the fact relatives

\footnotetext{
52 TNA F01024/101, British Governor, Allied National Prison, Werl to Penal Branch, Legal Advisor's Zonal Office, 13 July 1950.

53 TNA F01024/101, J.C. Piegrome to E.R. Vickers, 19 July 1950.

${ }^{54}$ TNA F01024/101: Letter from F.H. Rogers, British Governor Hameln Prison to Cemetery Director, 2 February 1948: 'Graves of Executed Prisoners'. This document also noted the presence of wreathes and signs that at least one grave was being tended.
} 
had been denied the right to mourn the dead at a proper, marked graveside. The popular weekly, Illustrierte Post, for example, sensationalised the fact that the tending of these sites in any form had been strictly forbidden and described how any flowers that were delicately placed in the vicinity were cruelly thrown away by the British staff. 55

While such articles repeatedly implied that the British had behaved in a cruel, callous or inhumane manner, the Nazi perpetrators were treated in a far more sympathetic manner. The press routinely used inverted commas around the term 'war criminal', implicitly casting doubt on their involvement in Nazi atrocities. The Illustrierte Post referred to the dead as 'political detainees', while both the tabloid Bild Zeitung and the Hannoversche Allgemeine Zeitung used the term 'survivors' to refer to those war criminals who had been transferred from Hameln to another prison. ${ }^{56}$ The corpses, then, were portrayed as victims of defeat, occupation and victors' justice - a sentiment that fitted into wider currents of German victimhood that circulated in the immediate post-war era. ${ }^{57}$ Bild-Zeitung labelled the prison burial ground a 'Yard of Horror', while at the most extreme, 'news' of the Hameln bodies was presented as the equivalent of the discovery of the Katyn massacre, suggesting that the effects of Josef Goebbels's wartime propaganda still held some resonance for elements of the German population.58 At no point in these articles was there any meaningful engagement with the crimes these former Nazis had committed. A memorandum within the UK High Commission in Germany noted:

\footnotetext{
55 Illustrierte Post, 'Secret 202: Though the Grass Grew Above', 8 August 1953. On 26 November 1953, the Illustrierte Post also published a reader's letter from former SS-Unterscharführer, Horst Gaede, who had himself only recently been released from serving a prison sentence for war crimes. Gaede had not actually been held in Hameln, and his letter was full of factual errors yet the press appeared to have no qualms about printing his rhetoric on the 'terrible British war crime'.

56 Bild Zeitung, 'German Mass Grave in Hameln Penitentiary', 26 November 1953; Hannoversche Allgemeine Zeitung, 'Menschlicher Abschluss der Zuchthaustragoedie in Hameln: sämtliche Namen trotz Allierter Geheimhaltung ausfindig gemacht', 3 March 1954.

57 On the theme of German victimhood see: Bill Niven ed., Germans as Victims: Remembering the Past in Contemporary Germany (Basingstoke, 2006); Robert G. Moeller, War Stories: The Search for a Usable Past in the Federal Republic of Germany (Berkeley, 2003); Neil Gregor, "'Is he still alive, or long since dead?": Loss, Absence and Remembrance in Nuremberg, 1945-1956', German History, Vol. 21, No. 2 (2003) pp. 183-203; Michael L. Hughes, “'Through No Fault of Our Own": West Germans Remember Their War Losses', German History, Vol. 18, No. 2 (2000) pp. 193-213. 58 Bild Zeitung, 'German Mass Grave in Hameln Penitentiary', 26 November 1953; Der Fortschritt, 'Katyn an der Weser', 4 December 1953.
} 
Fortschritt... [a Neo-Nazi publication] complains that the people buried in Hameln were denied a proper funeral such as is accorded to even a common murderer. It might be worthwhile pointing out that the people concerned were extremely uncommon murderers...59

This message, though, did not appear to sink in.

Finally, in early 1954, the government of Lower Saxony announced the exhumation and reburial of the remains interred in the grounds of Hameln prison. Bild-Zeitung was one of several newspapers to express its hope that this meant 'the dead will find... that peace which has so long been denied them'.60 The Finance Ministry of Lower Saxony pledged DM20,000 to cover the cost of providing individual coffins and burial plots for the remains, yet the Land government actually opted to continue earlier Allied policy and rebury the corpses in mass rather than individual graves. Despite the recent blaze of publicity surrounding the executed war criminals, it was also decided to try and rebury them on an undisclosed date, away from the prying eyes of the press or potential demonstrators. In part, this move appears to have been successful; there is no report on the reburial of the remains in the local Hameln press, other than a brief piece announcing the town's intentions in March 1954.61 At the same time, though, it appears that at least five of the criminal corpses were identified, and four of these were exhumed yet again and transferred to alternative cemeteries, presumably sites of familial significance. ${ }^{62}$

The reburial of convicted, executed war criminals also proved highly contentious within the international community. Foreign governments, Jewish organisations and Holocaust survivors' groups spoke of a 'posthumous whitewashing of Nazi

\footnotetext{
59 TNA FO 1060/4122, Memorandum by the Information Services Division, United Kingdom High Commission in Germany, 'Graveyard in Hameln Prison', 1 December 1953. Author's emphasis.

${ }^{60}$ Bild Zeitung, 'German Mass Grave in Hameln Penitentiary', 26 November 1953.

${ }^{61}$ Dewezet, 'Umbettung von Zuchthaus zum Wehlfriedhof' (3 March 1954).

62 The names of these individuals have been added to the cemetery records. Stadtarchiv Hameln, Best. 163 Nr. 68, Bestattungsregister Friedhof 'am Wehl' v. 18.3.52-31.12.61. The war criminals concerned include Willi Mackensen, executed in March 1946 for the ill-treatment of Allied prisoners of war during the 'evacuation march' from Thorn, Poland to Hannover in early 1945; and Friedrich Hollborn, former chief of the Hagen Gestapo executed for his role in the deaths of Canadian prisoners of war. In March 1955, Hollborn's remains were transferred to his birthplace of Osnabruck.
} 
killers' and took the reburial as evidence of a re-emerging fascism. Leicester MP Barnett Janner declared that the whole situation constituted a 'new myth of martyrdom' within the Federal Republic, while a statement from the World Jewish Congress declared that the reburial 'mocks the memory of Hitler's countless murdered victims' and questioned West Germany's place among civilised nations.63 Addressing concerns in the House of Commons, Anthony Eden refused to bow to pressure to make an official protest to the Federal Republic, stating, 'I am not prepared to pursue hatred beyond the grave'.64 Commentators within the British Foreign Office, however, privately dismissed the reburial as an act of 'extraordinary stupidity'.65 Undiscouraged, German officials back in Lower Saxony insisted that they were only acting out of concern for the relatives, rather than any political motives. They also made it clear that by transferring the remains to a more accessible, public place they hoped to quickly put an end to local, 'undesirable agitation'.66 Again, then, we see the expectation that the past can - quite literally - be buried once and for all, enabling the nation as a whole to move on.

\section{The Significance of the Hameln Executed Corpses}

The Hameln controversy reveals an almost cyclical process of silence or reticence about the past, followed by moments of highly emotive protest, and then a desire to draw a line under the whole Nazi legacy once and for all. This case study clearly highlights the limits of Holocaust engagement in post-war West Germany, and the continuing evasions and distortions that affected public retellings of the recent past. By examining the reactions to the reburial of the Hameln corpses, we can identify the tension between the genuine grief of the

\footnotetext{
${ }^{63}$ Hansard, Parliamentary Questions for 15 March 1954; TN F0371/109722, Statement by the World Jewish Congress, 4 March 1954. Protests and petitions were also received by the Board of Deputies of British Jews, the Association of Jewish Ex-Servicemen and Women, the National Assembly of Women, the British Legion and various trade unions.

${ }^{64}$ Hansard, Parliamentary Questions for 15 March 1954. Eden's response became the official line on the matter, with copies of his statement being sent out in response to every petition against the reburials.

65 TNA F0371/109722, Minute by H.W. Evans on the Reburial of War Criminals at Hameln, 8 March 1954.

${ }^{66}$ Ibid. On German responses to international criticism, see also Dewezet, 'Umbettung vor dem Unterhaus', (15 March 1954) which argued that no one should be allowed to deny the bereaved the chance to mourn their losses.
} 
war criminals' relatives, and a wider reluctance to countenance the fact that the perpetrators of the Holocaust could be devoted family men and women. The preferred West German image of National Socialism throughout the post-war period was one that depicted it as coming from 'somewhere else'. There was a retreat into local customs and traditions after 1945 in an attempt to present an alternative, healthier German history and portray Nazism as an alien force, an aberration. ${ }^{67}$ The remains of executed war criminals under local soil, however, challenged these post-war community narratives.

When justifying the decision to rebury those interred in the prison grounds, the authorities in Lower Saxony spoke of the sympathy that had to be extended for the 'embarrassed' relatives of some of the 'less notorious criminals' ${ }^{68}$ It was a comment that again suggested a lack of understanding regarding the organisation of the Holocaust, and an unwillingness to accept the guilt of all of the executed. Here, then, was a means of trying to reconcile the image of weeping relatives to the Hameln bodies: distinguishing between the likes of Josef Kramer - 'the Beast of Belsen' - and the rest of the executed facilitated the belief that very few of these corpses belonged to major offenders. As a result, the blame for Nazi atrocities could, in turn, be placed on a just a radical, sadistic few. Such logic could, of course, only be facilitated by not asking awkward questions about the events of the Third Reich.

Examining the post-execution history of Nazi war criminals raises the issue as to whether there are perpetrators who have committed such heinous crimes that they have forsaken all right to have a 'decent' funeral. Certainly for many former victims of Nazism, even hanging was seen as 'too good' for the war criminals, let alone the prospect of a neatly tended, marked individual grave. Others, however, refuted this, arguing that showing respect for the dead, whoever they may have been in life, was a fundamental moral duty, regardless of religious faith. In the midst of the Hameln reburial controversy, for example, the Jewish publisher and

\footnotetext{
${ }^{67}$ On this theme, see: Alon Confino, Germany as a Culture of Remembrance: Promises and Limits of Writing History (Chapel Hill, 2006); Ceila Applegate, A Nation of Provincials: The German Idea of Heimat (Berkeley, 1992).

68 TNA F0371/109722, Memorandum from Hannover to the Foreign Office, 5 March 1954.
} 
humanitarian campaigner Victor Gollancz wrote: 'to object to the burying of anyone whomever in hallowed ground is unseemly and unreligious for it suggests that God is as unmerciful and unforgiving as man.'69 Viewed in this light, proper burial of all the war dead, be they soldiers, civilians or perpetrators, could be seen as a necessary requisite for true post-conflict reconciliation. Gollancz, however, remained rather an isolated figure on this matter; the Hungarian-Jewish émigré publisher Paul Elek retorted that Gollancz was displaying a 'singular lack of imagination', and that the reburial process amounted to a 'symbolic act of defiance' against the Allies and a 'negation of the verdicts of the Nuremberg and similar tribunals'.70

Regardless of the public and political protest, the reburial of the Hameln executed war criminals was carried out in 1954 and the cemetery subsequently became a focal point for Neo-Nazi rallies and veterans' reunions. In September 1959, for example, a meeting of the HIAG (Mutual Help Association of Former Waffen-SS Members) attracted a crowd of 15,000 people including Josef 'Sepp' Dietrich, a highly decorated former Waffen-SS general who had previously been convicted by both US Military Tribunal and the Landgericht Munich for war crimes; the event concluded with comrades gathering around the tomb of Bernhard Siebken who, like Dietrich, had been a member of Hitler's personal bodyguard. ${ }^{71}$ Further controversy ensued in 1985 when the site witnessed demonstrations by the Neo-Nazi Free German Workers' Party (FAP). ${ }^{72}$ Yet interest in the executed criminal corpses was not confined to Far-Right extremists. On the contrary, between 1975 and 1986, a voluntary Bürgerinitiative (literally, citizens' initiative) was established specifically to tend and maintain the graves, underscoring the persistence of competing, local memories of the war years.

\footnotetext{
69 Victor Gollancz, 'Letter to The Times', 6 March 1954.

70 Paul Elek, 'Letter to The Times', 9 March 1954.

${ }^{71}$ Siebken had been executed in Hameln in 1949 for the shooting of Canadian prisoners of war. Dietrich, meanwhile, had been released from prison on grounds of ill-health. He continued to be a figurehead for the HIAG and his funeral, in 1966, attracted thousands of mourners, including many of his former comrades. Another HIAG convention was planned for Hameln in 1963 but was cancelled on that occasion due to public pressure.

72 Dewezet, 'Besucher fassungslos: Schlägerei auf Friedhof am Wehl' (18 November 1985) and 'Friedhofstumult beschäftigt Landtag' (23 November 1985).
} 
Formed in response to a town council proposal to level the site, the Bürgerinitiative insisted it was 'not a political group or a circle of comrades or the bereaved', but a group keen to protect the graves of 'victims of war and the postwar era', regardless of their nationality. ${ }^{73}$ In a peculiar turn of events, once people had come forward to assume responsibility for Plot CIII, the site was allowed to persist; CI, however, was levelled, creating a situation where perpetrators could be remembered while the graves of their victims were allowed to disappear. Furthermore, the Bürgerinitiative's activities went beyond simply keeping the cemetery plot free from weeds. On the eve of Volkstrauertag (National Day of Mourning), 1975, it placed a series of wooden crosses and wreathes on the site, a move that again equated the executed war criminals with victims of war and tyranny. ${ }^{74}$ Subsequent years also saw attempts at producing individual memorial plaques for each of the executed war criminals and in 1978 there was even a short-lived proposal to erect a permanent memorial, complete with the inscription, 'crime and punishment - misery and death - victims and retribution' ${ }^{75}$

Earlier postwar mythologies of German victimhood, Allied aggression and victors' justice thus continued to flourish in the late 1970s and beyond. It was not until 1986, in the wake of the FAP demonstrations and a related television documentary on the cemetery, that the town council finally took the decision to

\footnotetext{
73 Dewezet, 'Bürgerinitiative zur Erhaltung der Hingerichteten-Gräber' (20 November 1975). On the proposal to level the site, see Dewezet, 'Die Hingerichteten-Gräber am Wehl sollen jetzt eingeebnet werden' (3 November 1975). On responses to this, see Dewezet, 'Die HingerichtetenGräber am Wehl sollen nicht einfach verschwinden' (12 December 1975) and readers' letters, 13 November 1975. A protest organised by the Bürgerinitiative against the levelling of the graves received 1500 signatures - see Dewezet, 'Um die Hingerichteten-Gräber am Wehl' (1 March 1976).

${ }^{74}$ Dewezet, 'Bürgerinitiative zur Erhaltung der Hingerichteten-Gräber' (20 November 1975). During the 1970s, the Volksbund Deutsche Kriegsgräberfürsorge also held a series of youth camps in Hameln, encouraging young volunteers to respect and maintain war graves. On at least one occasion, Plot CIII was included in these efforts too. See Dewezet, 'Volkstrauertag Gedenkfeier nur für die "Offiziellen"? (12 November 1977) and Stadtarchiv Hameln, Best. 67 Acc. 1995/27 Nr. 231.

75 Bernhard Gelderblom, 'Das Zuchthaus Hameln in der Nachkriegszeit: Der Umgang mit den Gräbern der Hingerichteten in Hameln. Die Jahre 1975 bis 1985', http://www.gelderblomhameln.de/zuchthaus/nachkriegszeit/1019751985.html (Accessed 19 July 2013).
} 
completely level Plot CIII as well. ${ }^{76}$ It was a move that came a year after Ronald Reagan's inflammatory visit to Bitburg Military Cemetery (which contained SS graves), and in the midst of the widely-publicised Historikerstreit in which leading West German historians debated the very need to keep talking about the Nazi past. ${ }^{77}$ By removing the crosses and levelling the burial site in Hameln, the notion re-emerged that destroying physical reminders of Nazism would render it truly dead, harking back to the Allies' original intentions.

Today, the public narrative of the Second World War in Hameln is reversed: Plot CIII is overgrown with stinging nettles and other weeds while memorial stones have been placed in both $\mathrm{CI}$ and outside the former Hameln prison to remember those killed by the Nazis; likewise, the noticeboard at the entrance to the cemetery highlights the location of CI while CIII is omitted altogether. ${ }^{78}$ Yet the memory of the executed war criminals has not completely faded. The growing popularity of amateur genealogy reveals the layers of knowledge and competing patterns of remembrance within online resources. The website findagrave.com, for example, gives people around the world the opportunity to trace their ancestors' final resting places, as well as listing various famous graves. Their records for Hameln recall some of the Bergen-Belsen concentration camp personnel executed in December 1945, including Irma Grese. Public comments have been disabled for her page, suggesting that this function has previously been abused by Nazi sympathisers. However, the comments feature is still operational for two of her former comrades, Juanna Bormann and Elisabeth Volkenrath and has resulted in lines such as 'Germany is rising' and 'sleep softly'.

\footnotetext{
${ }^{76}$ See Dewezet, 'Antrag an den Stadtrat: SPD will Hingerichtetengräber einebnen' (27 November 1985); 'Die altern Gräber bergen Hinrichtungs-Schicksale' (4 December 1985); 'Emotionen belasteten Debatte um Hingerichtetengräber' (13 December 1985); 'Ratsbeschluß ein Skandal?' (17 December 1985); 'Nach TV-Besuch im Rat: Wehl weiter Nazi-Kultert?' (1 March 1986); 'Stadtverwaltung zog Schlußstrich unter Friedhofs-Affäre. Hingerichtetengräber eingeebnet' (6 March 1986). Given the unfavourable publicity that the FAP demonstration created for Hameln, it could be argued that the subsequent actions of the town council were motivated more by public relations concerns than a genuine engagement with the crimes of the Third Reich.

77 On these events, see, for example: Geoffrey Hartman ed., Bitburg in Moral and Political Perspective (Bloomington, 1986); Geoff Eley, 'Nazism, Politics and the Image of the Past: Thoughts on the West German Historikerstreit, 1986-1987', Past and Present, Vol. 121 (1988) pp. 171-208; Richard Evans, In Hitler's Shadow: West German Historians and the Attempt to Escape from the Nazi Past (London, 1989).

${ }_{78}$ Author's observations, July 2013.
} 
Another comment on Volkenrath's page reads, 'the face of evil? No! The face of an innocent young girl'.79 People can leave virtual flowers and commemorative notes for these individuals - and use this space to remember Grese too. A comment on Bormann's page, for instance, states, 'these flowers are for your beautiful comrade IRMA GRESE $\mathrm{xx}^{\prime}{ }^{80}$ While the comments are anonymous, it is a behaviour that echoes previous efforts to locate and individualise the war criminals graves, be it the emotive search for more information by grieving relatives in the 1940s and 1950s, or the determined efforts to memorialise the cemetery space by volunteers in the 1970s and 1980s. In each case, it is evident that the post-execution history of these perpetrators continues to resonate. Eradicating physical traces of the dead is not sufficient to 'bury the past'; their memory continues to live on in other ways.

${ }^{79}$ FindAGrave.com, 'Elisabeth Volkenrath' (http://www.findagrave.com/cgi-

bin/fg.cgi?page $=$ gr\&GRid $=67286709$ )

${ }^{80}$ FindAGrave.com, 'Juana Bormann' (http://www.findagrave.com/cgi-

bin/fg.cgi?page=gr\&GScid=2394121\&GRid=67494633\&), accessed 25 April 2013. 